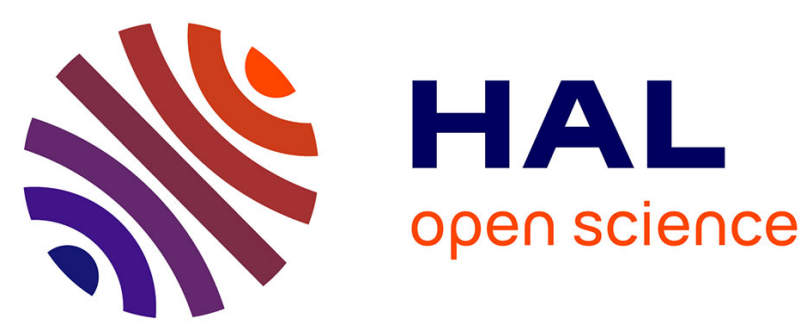

\title{
Adipose tissue compensates for defect of phosphatidylinositol 3'-kinase induced in liver and muscle by dietary fish oil in fed rats
}

Charlotte Corporeau, Christelle Le Foll, Mohammed Taouis, Jean-Paul

Gouygou, Jean-Pascal Bergé, Jacques Delarue

\section{To cite this version:}

Charlotte Corporeau, Christelle Le Foll, Mohammed Taouis, Jean-Paul Gouygou, Jean-Pascal Bergé, et al.. Adipose tissue compensates for defect of phosphatidylinositol 3'-kinase induced in liver and muscle by dietary fish oil in fed rats. AJP - Endocrinology and Metabolism, 2006, 290 (1), pp.E78-E86. 10.1152/ajpendo.00200.2005 . hal-02548648

\section{HAL Id: hal-02548648 \\ https://hal.science/hal-02548648}

Submitted on 29 May 2020

HAL is a multi-disciplinary open access archive for the deposit and dissemination of scientific research documents, whether they are published or not. The documents may come from teaching and research institutions in France or abroad, or from public or private research centers.
L'archive ouverte pluridisciplinaire HAL, est destinée au dépôt et à la diffusion de documents scientifiques de niveau recherche, publiés ou non, émanant des établissements d'enseignement et de recherche français ou étrangers, des laboratoires publics ou privés. 
Charlotte Corporeau, Christelle Le Foll, Mohammed Taouis, Jean-Paul Gouygou, Jean-Pascal Bergé and Jacques Delarue

Am J Physiol Endocrinol Metab 290:78-86, 2006. doi:10.1152/ajpendo.00200.2005

You might find this additional information useful...

This article cites 36 articles, 24 of which you can access free at:

http://ajpendo.physiology.org/cgi/content/full/290/1/E78\#BIBL

This article has been cited by 2 other HighWire hosted articles:

Long-chain n-3 polyunsaturated fatty acids dissociate phosphorylation of Akt from phosphatidylinositol 3'-kinase activity in rats

C. Le Foll, C. Corporeau, V. Le Guen, J.-P. Gouygou, J.-P. Berge and J. Delarue

Am J Physiol Endocrinol Metab, April 1, 2007; 292 (4): E1223-E1230.

[Abstract] [Full Text] [PDF]

Glucocorticoids produce whole body insulin resistance with changes in cardiac metabolism

D. Qi and B. Rodrigues

Am J Physiol Endocrinol Metab, March 1, 2007; 292 (3): E654-E667.

[Abstract] [Full Text] [PDF]

Medline items on this article's topics can be found at http://highwire.stanford.edu/lists/artbytopic.dtl on the following topics:

Biochemistry .. Glucose Homeostasis

Biochemistry .. Glucose Transport

Medicine .. Insulin

Oncology .. Insulin Signaling

Oncology .. Insulin-Dependent Signal Transduction

Physiology .. Rats

Updated information and services including high-resolution figures, can be found at:

http://ajpendo.physiology.org/cgi/content/full/290/1/E78

Additional material and information about AJP - Endocrinology and Metabolism can be found at: http://www.the-aps.org/publications/ajpendo

This information is current as of September 2, 2010 .

AJP - Endocrinology and Metabolism publishes results of original studies about endocrine and metabolic systems on any level of organization. It is published 12 times a year (monthly) by the American Physiological Society, 9650 Rockville Pike, Bethesda MD 20814-3991. Copyright @ 2006 by the American Physiological Society. ISSN: 0193-1849, ESSN: 1522-1555. Visit our website at http://www.the-aps.org/. 


\title{
Adipose tissue compensates for defect of phosphatidylinositol 3'-kinase induced in liver and muscle by dietary fish oil in fed rats
}

\author{
Charlotte Corporeau, ${ }^{1}$ Christelle Le Foll, ${ }^{1}$ Mohammed Taouis, ${ }^{2}$ \\ Jean-Paul Gouygou, ${ }^{3}$ Jean-Pascal Bergé, ${ }^{3}$ and Jacques Delarue ${ }^{1}$ \\ ${ }^{1}$ Equipe d'Accueil 948 "Oxylipides", Faculté de Médecine, Brest; ${ }^{2}$ Laboratoire d'Endocrinologie \\ de la Nutrition, Faculté des Sciences, Orsay; and ${ }^{3}$ Département Génie Alimentaire, Ifremer, Nantes, France
}

Submitted 5 May 2005; accepted in final form 14 July 2005

\begin{abstract}
Corporeau, Charlotte, Christelle Le Foll, Mohammed Taouis, Jean-Paul Gouygou, Jean-Pascal Bergé, and Jacques Delarue. Adipose tissue compensates for defect of phosphatidylinositol $3^{\prime}$-kinase induced in liver and muscle by dietary fish oil in fed rats. Am J Physiol Endocrinol Metab 290: E78-E86, 2006; doi:10.1152/ajpendo.00200.2005. - The present work aimed to study in rats whether substitution of a low level of fish oil (FO; $2.2 \%$ of calories) into a low-fat diet $(6.6 \%$ of calories from fat as peanut-rape oil or control diet) 1) has a tissue-specific effect on insulin signaling pathway and 2) prevents dexamethasone-induced alteration of insulin signaling in liver, muscle, and adipose tissue. Sixteen rats were used for study of insulin signaling, and sixteen rats received an oral glucose load $(3 \mathrm{~g} / \mathrm{kg})$. Eight rats/group consumed control diet or diet containing FO over 5 wk. Four rats from each group received a daily intraperitoneal injection of saline or dexamethasone $\left(1 \mathrm{mg} \cdot \mathrm{kg}^{-1} \cdot \mathrm{day}^{-1}\right)$ for the last 5 days of feeding. In liver, FO decreased phosphatidylinositol 3 '-kinase (PI $3^{\prime}$-kinase) activity by $54 \%$ compared with control diet. A similar result was obtained in muscle. In both liver and muscle, FO clearly amplified the effect of dexamethasone. FO did not alter early steps of insulin signaling, and in muscle GLUT4 protein content remained unaltered. In adipose tissue, FO increased PI 3'-kinase activity by $74 \%$, whereas dexamethasone decreased it by $65 \%$; inhibition of PI 3'-kinase activity by dexamethasone was similar in rats fed FO or control diet, and GLUT4 protein content was increased by $61 \%$ by FO. Glycemic and insulinemic responses to oral glucose were not modified by FO. In conclusion, FO increased PI $3^{\prime}$-kinase activity in adipose tissue while inhibiting it in liver and muscle. The maintenance of whole body glucose homeostasis suggests an important role of adipose tissue for control of glucose homeostasis.
\end{abstract}

eicosapentaenoic acid; docosahexaenoic acid; insulin resistance; polyunsaturated fatty acids

INSULIN RESISTANCE is a common characteristic of type 2 diabetes, obesity, and metabolic syndrome (31), which results from genetic background and/or environmental factors (39). In patients with type 2 diabetes, liver, skeletal muscle, and adipose tissue are resistant to insulin action (8). In skeletal muscle of patients with type 2 diabetes, tyrosine phosphorylation of insulin receptor (IR) and insulin receptor substrate-1 (IRS-1) and phosphatidylinositol (PI) 3'-kinase activity are markedly impaired (5), whereas expressions of IR, IRS-1, or the $\mathrm{p} 85 \alpha$ subunit of PI 3'-kinase remain unaltered (17). Muscle GLUT4 protein is decreased and GLUT4 translocation is reduced by $90 \%$ during hyperinsulinemia (27). These alterations of insulin signaling in muscle participate in the decrease in muscle

Address for reprint requests and other correspondence: J. Delarue, Equipe d'Accueil 948 "Oxylipides", Faculté de Médecine, 22 Ave. Camille Desmoulins, CS 93837 F-29238 Brest Cedex 3, France (e-mail: jacques.delarue@univ-brest.fr). glucose transport, one of the main features of type 2 diabetes (7). In adipose tissue, basal expression of GLUT4 and IRS-1 are reduced, and upregulation of $\mathrm{p} 85 \alpha$ by insulin is completely blunted (11).

In rats, a high-fat diet $(60 \%$ of calories from fat as safflower oil) inhibits liver and muscle PI 3 '-kinase activity (35). In addition, muscle GLUT4 content and adipose tissue GLUT4 gene expression are reduced (35). These alterations likely explain the impairment of glucose transport in these tissues and at whole body level (33). When fish oil (FO), rich in long-chain n-3 polyunsaturated fatty acids (LC-n-3 PUFA), is substituted for one-third into the lipid fraction of the diet, insulin resistance is completely prevented (32-34). The decreases in both muscle PI 3'-kinase activity and GLUT4 content are completely prevented, as is the decrease in adipose tissue GLUT4 gene expression (35). However, reduction of liver PI 3 '-kinase activity remains unaffected (35). Thus a high level (20\% of calories) of FO affects insulin signaling in a tissue-specific manner but completely prevents whole body, liver, and muscle insulin resistance in vivo (34).

Dexamethasone treatment induces insulin resistance in both rats (28) and humans (37), which is sustained by alterations of insulin signaling in liver and muscle, mainly a reduction of insulin-stimulated IRS-1-associated PI 3'-kinase activity and of GLUT4 translocation $(10,40)$. Both abnormalities are also present in muscle of patients with type 2 diabetes $(5,17)$ and of high fat-fed rats (35). Thus dexamethasone treatment in rats is an interesting model of induced insulin resistance to study the effects of a low level of LC-n-3 PUFA without altering other dietary parameters which could interfere with insulin sensitivity.

The present work aimed to study in fed rats and in the physiological state (without exogenous insulin treatment) 1) whether substitution of a low level of FO [2.2\% of calories, i.e., $0.42 \%$ eicosapentaenoic acid (EPA) + docosahexaenoic acid (DHA)] into a low-fat diet $(6.6 \%$ of calories from fat as peanut-rape oil) has a tissue-specific effect on the physiological insulin-signaling pathway activation (fed state) and 2) whether such a low level of FO prevents dexamethasone-induced alterations of insulin signaling in liver, muscle, and adipose tissue.

\section{MATERIALS AND METHODS}

Animal care and tissue preparation. Thirty-two male Wistar rats aged $5 \mathrm{wk}$ were housed in a temperature-, humidity-, and lightcontrolled room. Over the first $5 \mathrm{wk}$ preceding the study, rats were fed

The costs of publication of this article were defrayed in part by the payment of page charges. The article must therefore be hereby marked "advertisement" in accordance with 18 U.S.C. Section 1734 solely to indicate this fact. 
ad libitum with a standard chow diet (59\% of calories from carbohydrates, $7 \%$ from fat, $21 \%$ from protein, $13 \%$ from minerals and ash). Sixteen rats were killed in the fed state and not after insulin injection, in order to study insulin signaling in liver, muscle, and adipose tissue in a true physiological state. Sixteen additional rats were used for study of glycemic and insulinemic responses to an oral glucose load.

For each group, rats were randomly divided into two groups $(n=$ 8/group) and placed on either a normolipidic diet containing n-6 PUFA (control diet) or LC-n-3 PUFA (n-3 diet) with water ad libitum. Diets were prepared by Atelier de Préparation Aliments Expérimentaux (APAE, INRA, Jouy-en-Josas, France). The control diet contained $6.6 \%$ of calories from fat as peanut-rape oil, $22 \%$ from casein, $43 \%$ from starch, and $28.4 \%$ from sucrose. The n-3 diet contained $4.4 \%$ of calories from fat as peanut-rape oil, $2.2 \%$ from fat as FO, $22 \%$ from casein, $43 \%$ from starch, and $28.4 \%$ from sucrose. Before the end of the 4-wk period, animals in all groups were randomly subdivided into two groups of four rats to receive a daily intraperitoneal injection of saline or dexamethasone $\left(1 \mathrm{mg} \cdot \mathrm{kg}^{-1} \cdot \mathrm{day}^{-1}\right)$ for 5 days. The dose of dexamethasone was chosen to induce insulin resistance, as described by Saad et al. (28). Animals were killed in the fed state. To minimize differences in time of being euthanized between treatments, four rats were chosen randomly in the four different groups and were killed simultaneously. All rats were killed in the morning before 10 AM. Blood was immediately collected, and the plasma was separated by centrifugation and stored at $-20^{\circ} \mathrm{C}$ until subsequent analysis. Liver, leg muscles (gastrocnemius, soleus, and biceps femoris), and epididymal fat tissue were immediately frozen, powdered into liquid nitrogen, and stored at $-80^{\circ} \mathrm{C}$. The protocol was performed in conformity with regulations for the care and use of laboratory animals (decree no. 87-848 from the French Department of Agriculture and Fishing).

Oral glucose tolerance test. After an overnight fast, a local anesthetization with lidocaine (EMLA 5\% cream; Astrazeneca, Rueilmalmaison, France) was performed on the tail, a vein blood sample was taken first, and then a glucose solution ( $3 \mathrm{~g} / \mathrm{kg}$ body wt) was orally administred. Blood samples were then collected at 10, 20, 30, $45,60,90$, and $120 \mathrm{~min}$. For each sample, a fraction was immediately used for glucose determination using a GLUCOTOUCH Pro glucometer (Lifescan), another fraction was collected in tubes containing heparin, and the plasma was separated by centrifugation. Plasma was stored at $-20^{\circ} \mathrm{C}$ until insulin concentration analysis.

Plasma glucose, insulin, and nonesterified fatty acid concentrations. Except for the oral glucose tolerance test (OGTT), glycemia was determined with the glucose oxidase method by using an automated multiparametric analyzer (Modular, Roche, Mannheim, Germany). Plasma insulin levels were determined by a radioimmunoassay kit (Linco Research, St. Charles, MO) using rat insulin as standard. Plasma nonesterified fatty acid (NEFA) concentrations were determined by a colorimetric method using a NEFA C kit (Wako Chemical, Neuss, Germany).

Extraction and analysis of lipids. Total lipid extracts from diets and rat tissues were obtained by the method of Bligh and Dyer (6). For rat tissues, neutral lipids, galactolipids, and phospholipids were successively eluted by $\mathrm{CHCl}_{3}$ ( $1 \mathrm{ml} / \mathrm{mg}$ crude lipids), $\mathrm{Me}_{2} \mathrm{CO}-\mathrm{MeOH}$ (9:1; $1.5 \mathrm{ml} / \mathrm{mg}$ crude lipids), and $\mathrm{MeOH}$ ( $1 \mathrm{ml} / \mathrm{mg}$ crude lipids), using the procedure previously described by Bergé et al. (3). Lipids were evaporated under nitrogen and transmethylated by contact with $\mathrm{MeOH}-\mathrm{H}_{2} \mathrm{SO}_{4}(98: 2)$ in excess for one night at $50^{\circ} \mathrm{C}$. After cooling, $2 \mathrm{ml}$ of pentane and $1 \mathrm{ml}$ of water were added and vortexed. The upper organic phases containing fatty acid methyl esters were collected and assayed by GC using a PerkinElmer Autosystem equipped with an FID detector. Separation was done using He as carrier gas on a fused silica column (BPX, $70.60 \mathrm{~m}$ long, $0.25 \mathrm{~mm} \mathrm{ID,} 0.25 \mu \mathrm{m}$ film thickness, SGE Analytical Science, Cortaboeuf, France) programmed from $55^{\circ} \mathrm{C}$ (for $2 \mathrm{~min}$ ) to $150^{\circ} \mathrm{C}$ at $20^{\circ} \mathrm{C} / \mathrm{min}$. Fatty acid methyl esters were identified by comparison of their equivalent chain lengths with those of authentic standards, and quantification was done using margaric acid (17:0) as internal standard $(4,20)$.

$I R$ density and affinity for insulin in liver membranes. Insulin binding to crude liver membranes was measured using ${ }^{125} \mathrm{I}$-labeled porcine insulin at $0.1 \mathrm{ng} / \mathrm{ml}$, as previously described (36). Tracer binding was inhibited by increasing concentrations of unlabeled monocomponent porcine insulin $(4-40,000 \mathrm{ng} / \mathrm{ml})$. After centrifugation, pellets were washed with $0.2 \mathrm{ml}$ of chilled sucrose $(0.25 \mathrm{M})$, and incorporated radioactivity was counted. Nonspecific binding was determined in the presence of an excess of cold insulin $(13.33 \mu \mathrm{g} / \mathrm{ml})$ and was found to be $2-7 \%$ of total binding. The competition curves were analyzed using Cricket Graph software (version 4.00).

Immunoprecipitation and Western blotting procedures. Powdered tissues $(1 \mathrm{~g})$ were solubilized in ice-cold buffer $A(150 \mathrm{mM} \mathrm{NaCl}, 10$ mM Tris, pH 7.4, 1 mM EDTA, 1 mM EGTA, $1 \%$ Triton X-100, 0.5\% Igepal, $2 \mathrm{mM}$ PMSF, $10 \mu \mathrm{g} / \mathrm{ml}$ leupeptin, $10 \mu \mathrm{g} / \mathrm{ml}$ aprotinin, 100 $\mathrm{mM}$ sodium fluoride, $10 \mathrm{nM}$ sodium pyrophosphate, and $2 \mathrm{mM}$ sodium orthovanadate). Tyrosine-phosphorylated proteins or IRS-1 were immunoprecipitated with specific antibodies (Upstate Biotechnology, Lake Placid, NY). Lysates or immunoprecipitates were separated by SDS-PAGE, and immunoblotting was performed using antibodies directed against either IR or the p85 $\alpha$ subunit of PI3'kinase (Santa Cruz Biotechnology, Santa Cruz, CA), IRS-1 (Upstate Biotechnology), or GLUT4 (Chemicon International). Blots were revealed by Immun-star AP detection kit (Bio-Rad, Hercules, CA). Band intensities were quantified by optical densitometry (Bio1D scanning software; Vilber Lourmat, France).

PI 3'-kinase activity. Powdered tissues $(1 \mathrm{~g})$ were solubilized in ice-cold buffer $B$ (137 mM NaCl, $20 \mathrm{mM}$ Tris, $\mathrm{pH} 7.5,1 \mathrm{mM} \mathrm{MgCl}$, $1 \mathrm{mM} \mathrm{CaCl}_{2}, 10 \%$ glycerol, $1 \%$ Igepal, $2 \mathrm{mM} \mathrm{PMSF}, 10 \mu \mathrm{g} / \mathrm{ml}$ aprotinin, and $0.1 \mathrm{mM}$ sodium orthovanadate). Tyrosine-phosphorylated proteins were immunoprecipitated using PY20 antibody (Upstate Biotechnology). After being washed, the immune complexes were used to measure PI 3 '-kinase activity as previously described (34). Phosphorylated PI was extracted and resolved onto silica gel TLC plate (Whatman, Middlesex, UK). TLC plates were developed in $\mathrm{CHCL}_{3}-\mathrm{CH}_{3} \mathrm{OH}-\mathrm{H}_{2} \mathrm{O}-\mathrm{NH}_{4} \mathrm{OH}$ (120:94:22.6:4), dried, and visualized by autoradiography. The radioactivity in spots that comigrated with a PI-4 standard was measured by Instant Imager (Hewlett-Packard).

Statistics. All results are expressed as means \pm SE. Statistical analyses were performed by using Mann-Whitney test. Software was Statview II (Abacus Concepts).

\section{RESULTS}

Characteristics of experimental rats. Dexamethasone treatment induced a decrease in weight and food intake $(P<0.05$; Table 1) as well as a marked increase in glycemia, insulinemia, and plasma NEFA concentrations $(P<0.05)$. The $n-3$ diet did not alter these effects of dexamethasone (Table 1).

Table 1. Animal characteristics during the 5-day period of dexamethasone treatment

\begin{tabular}{lcccc}
\hline \hline \multicolumn{1}{c}{ Diet and Parameters } & Control & $\mathrm{n}-3$ & $\begin{array}{c}\text { Control }+ \\
\text { Dexa }\end{array}$ & $\mathrm{n}-3+$ Dexa \\
\hline Body weight, g & $432 \pm 4$ & $424 \pm 9$ & $362 \pm 4^{*}$ & $369 \pm 4 *$ \\
Weight gain, g/5 days & $14 \pm 1$ & $13 \pm 1$ & $-44 \pm 2^{*}$ & $-37 \pm 3^{*}$ \\
Food intake, g/day & $20 \pm 1$ & $21 \pm 2$ & $9 \pm 2 *$ & $11 \pm 2^{*}$ \\
Glucose, mM & $9.6 \pm 0.2$ & $10.1 \pm 0.8$ & $19.3 \pm 4.3 *$ & $20.0 \pm 4.2^{*}$ \\
Insulin, nM & $0.71 \pm 0.15$ & $0.64 \pm 0.02$ & $3.14 \pm 0.22^{*}$ & $4.76 \pm 0.72 *$ \\
NEFA, mM & $0.45 \pm 0.02$ & $0.40 \pm 0.03$ & $1.35 \pm 0.22^{*}$ & $1.00 \pm 0.09^{*}$
\end{tabular}

Data are means $\pm \mathrm{SE} ; n=4$ rats. NEFA, nonesterified fatty acids. $* P<$ 0.05 vs. rats fed the same diet not treated with dexamethasone (Dexa). 
Effect of n-3 diet on glycemic and insulinemic responses to OGTT. Area under the curve (AUC) of glycemic and insulinemic responses to oral glucose were higher in rats treated with dexamethasone $(P<0.05$; Fig. 1$)$. The $n-3$ diet did not alter these effects of dexamethasone (Fig. 1).

Effect of $n-3$ diet on fatty acids content of membrane phospholipids of muscle, liver, and adipose tissue. Fatty acid content of membrane phospholipids of liver, muscle, and adipose tissue is shown in Fig. 2. The proportion of LC-n-3 PUFA into phospholipids of the three tissues was higher in rats fed the n-3 diet than in control rats, demonstrating their incorporation into membranes.

Effect of $n-3$ diet on IR, IRS-1, and PI 3 '-kinase in liver. The n-3 diet affected neither IR membrane density nor affinity (as estimated by $\mathrm{EC}_{50}$; control $=12.78 \pm 1.69 \mathrm{ng} / \mathrm{ml} ; \mathrm{n}-3=$ $15.29 \pm 1.03 \mathrm{ng} / \mathrm{ml}$ ) of insulin binding in liver. In contrast, dexamethasone treatment of both control and FO rats significantly reduced IR membrane density $(-26 \%)$ and affinity as estimated by $\mathrm{EC}_{50}$ (control + Dexa $=22.54 \pm 4.36 \mathrm{ng} / \mathrm{ml}$; $\mathrm{n}-3+$ Dexa $=30.02 \pm 4.95 \mathrm{ng} / \mathrm{ml})$. IR and IRS-1 protein contents were unchanged whatever the diet and treatment (Fig. $3, A$ and $C$ ). In dexamethasone-treated rats, the n-3 diet induced an $89 \%$ increase in IR tyrosine phosphorylation $(P<$
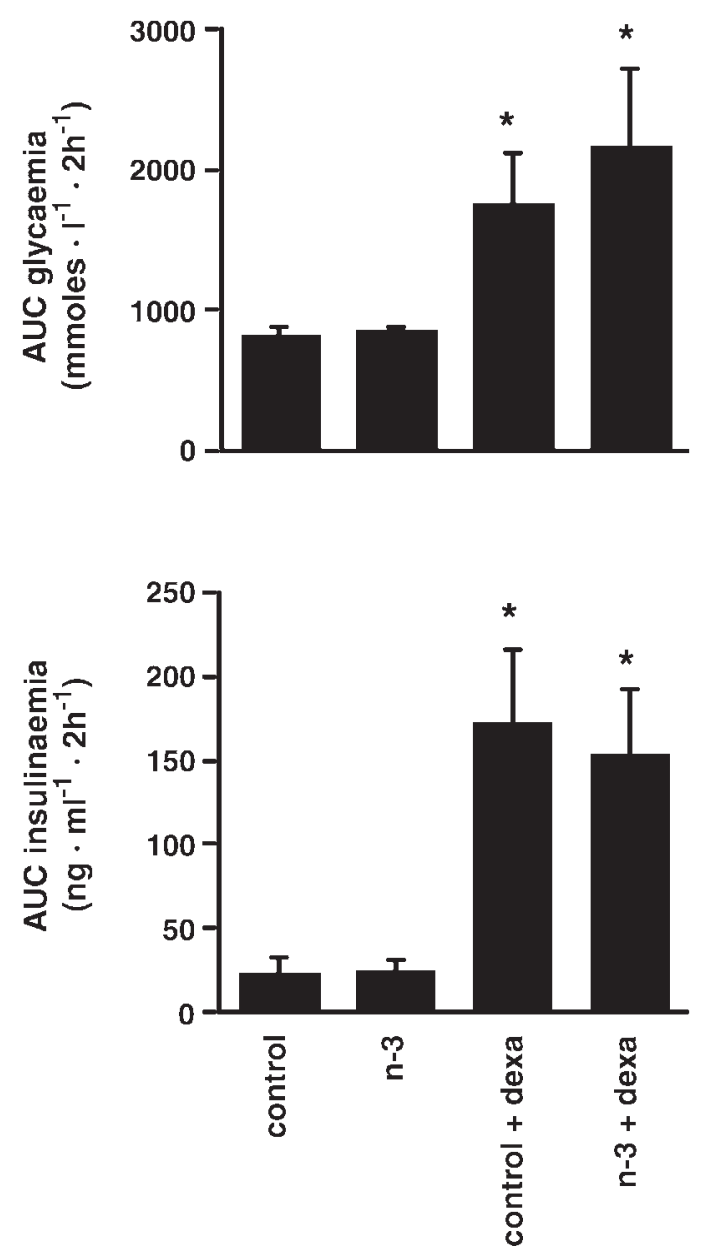

Fig. 1. Area under curve (AUC) of plasma glucose and insulin responses to an oral glucose challenge ( $3 \mathrm{~g} / \mathrm{kg}$ body $\mathrm{wt}$ ). Oral glucose tolerance test was performed in the morning after overnight fasting. dexa, Dexamethasone. Results are expressed as means $\pm \mathrm{SE} ; n=4$ rats. ${ }^{*} P<0.05$ vs. control.
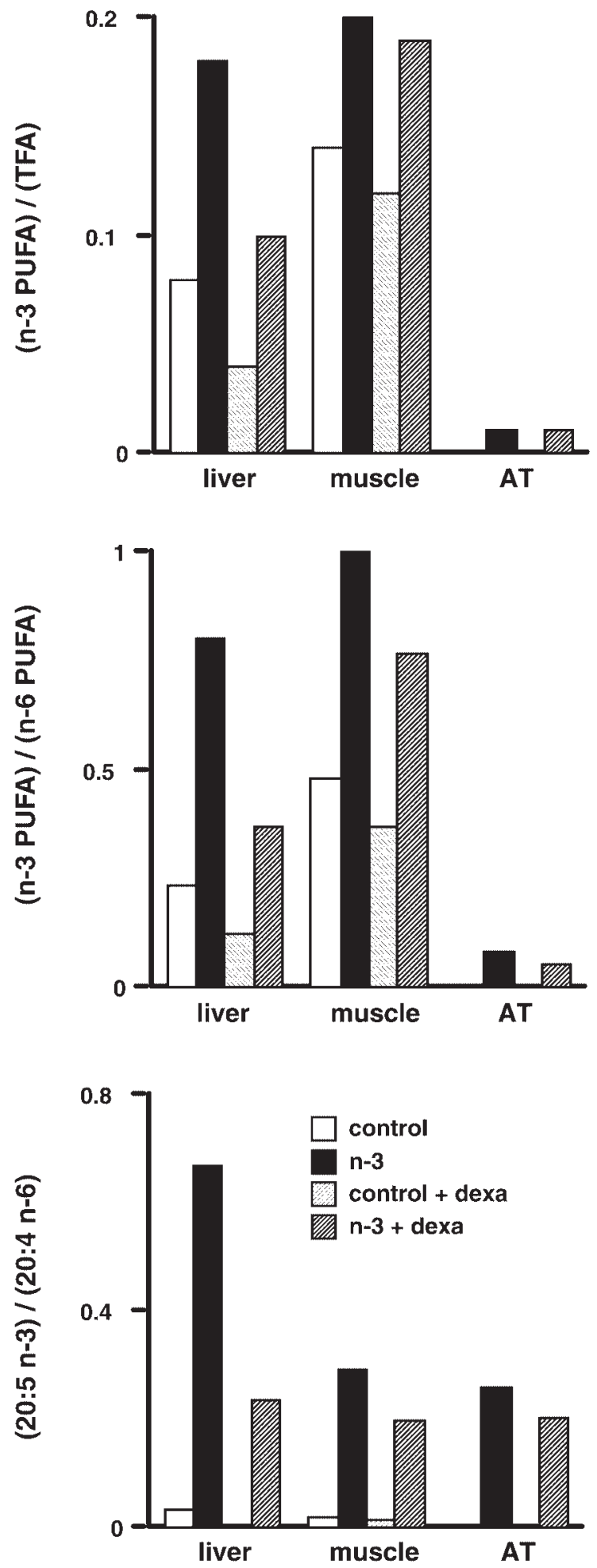

Fig. 2. Fatty acid composition of membrane phospholipids of liver, muscle, and adipose tissue (AT) expressed as n-3 polyunsaturated fatty acid (PUFA)/ total fatty acid (TFA), n-3 PUFA/n-6 PUFA, 20:5 n-3/20:4 n-6.

0.05 ; Fig. $3 B$ ) and a $46 \%$ increase in IRS-1 tyrosine phosphorylation $(P<0.05$; Fig. $3 D)$, whereas n-3 alone or dexamethasone alone had no effect. p85 $\alpha$ protein content and $\mathrm{p} 85 \alpha$ association with IRS-1 remained unchanged in liver whatever the diet and treatment (Fig. 3, $E$ and $F$ ). The n-3 diet inhibited 
A

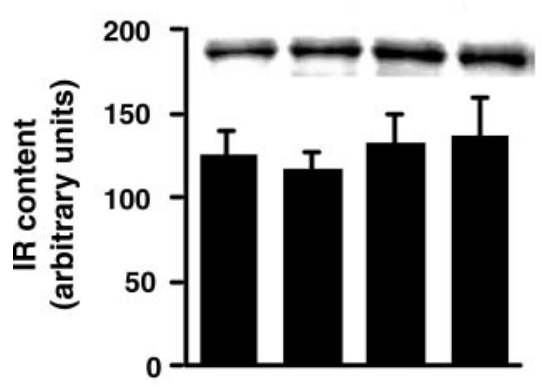

C

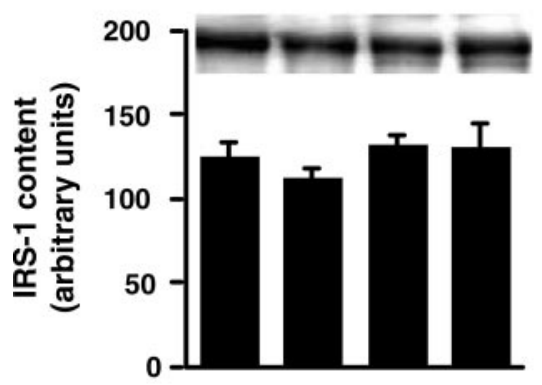

B
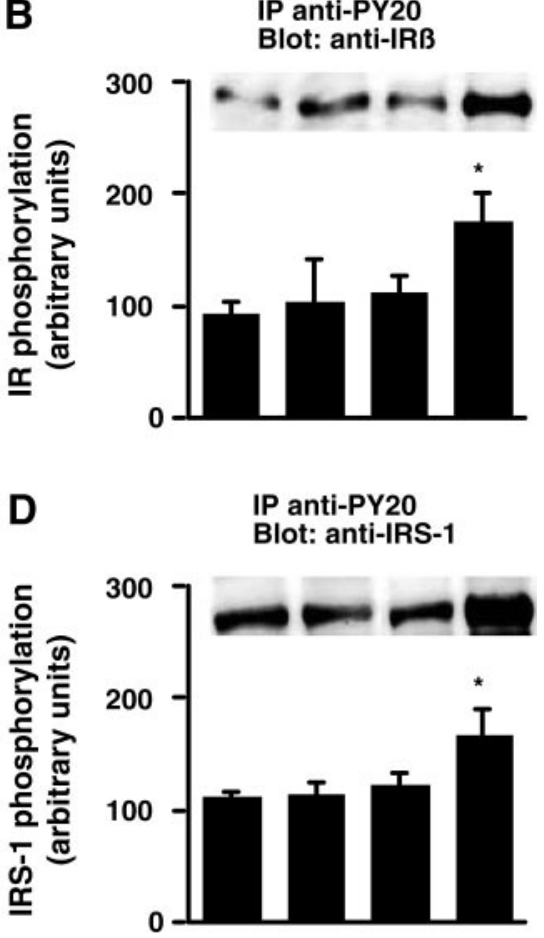

Fig. 3. Insulin receptor (IR), insulin receptor substrate-1 (IRS-1), and p85 $\alpha$ protein contents $(A, C, E)$, IR and IRS-1 tyrosine phosphorylation $(B$ and $D), \mathrm{p} 85 \alpha$ association with IRS-1 $(F)$, and phosphatidylinositol $3^{\prime}$-kinase (PI3K) activity $(G)$ in liver. To quantify protein contents, lysates $(100 \mu \mathrm{g})$ were electrophoresed onto $10 \%$ SDS polyacrylamide gel and blotted with anti-IR $\beta$ to identify the $\beta$-subunit of IR $(A)$, with antiIRS-1 $(C)$ or with anti-p85 $(E)$. For tyrosine phosphorylation, lysates $(1 \mathrm{mg})$ were immunoprecipitated (IP) with anti-PY20 and then blotted with anti-IR $\beta(B)$ or anti-IRS-1 $(D)$. To identify p85 $\alpha$ associated with IRS-1 $(F)$, lysates $(1 \mathrm{mg})$ were immunoprecipitated with antiIRS-1 and then blotted with anti-p85 $\alpha$. Results were quantified by densitometry. Blots are representative of 4 experiments. $G$ : PI3K activity was assayed in PY20 immunoprecipitates by quantification of ${ }^{32} \mathrm{P}$ incorporated into PI 3-phosphate $(\mathrm{PI}(3) \mathrm{P})$. Results are expressed as means $\pm \mathrm{SE} ; n=4$ rats. ${ }^{*} P<0.05$ vs. control; $\dagger P<0.05$ vs. control + dexa.

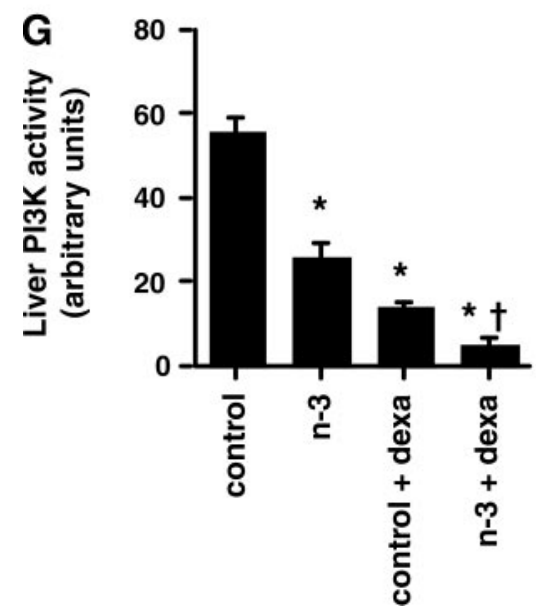

\section{Blot: anti-p85 $\alpha$}

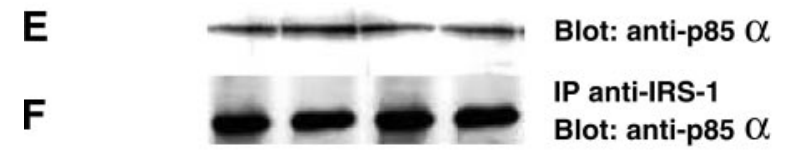

PI 3 '-kinase activity by $54 \%(P<0.05)$ (Fig. $3 G)$ and dexamethasone alone inhibited it by $75 \%(P<0.05)$. N-3 diet amplified dexamethasone-induced inhibition of PI 3 '-kinase activity from 75 to $91 \%(P<0.05$; Fig. $3 G)$.

Effect of $n-3$ diet on IR, IRS-1, PI 3'-kinase, and GLUT4 in muscle. In muscle, neither IR membrane density nor affinity toward insulin can be estimated using crude membranes due to the highly nonspecific binding of labeled insulin $(1,35)$. IR and IRS-1 protein contents were unchanged whatever the diet and treatment (Fig. 4, $A$ and $C$ ). In dexamethasone-treated rats, n-3 diet increased IR tyrosine phosphorylation $(P<0.05$; Fig. $4 B)$ but had no effect on IRS-1 tyrosine phosphorylation (Fig. 4D). Dexamethasone alone or n-3 alone had no effect either on IR or on IRS-1 tyrosine phosphorylation (Fig. 4, $B$ and D). p $85 \alpha$ protein content and p85 $\alpha$ association with IRS-1 remained unchanged in muscle whatever the diet and treatment (Fig. 4, $E$ and $F)$. The n-3 diet inhibited PI 3 '-kinase activity by $54 \%$ $(P<0.05$; Fig. $4 G)$; dexamethasone inhibited it by $82 \%(P<$ $0.05)$. The $\mathrm{n}-3$ diet amplified dexamethasone-induced inhibition of PI $3^{\prime}$-kinase activity from 82 to $91 \%(P<0.05$; Fig. $4 G)$. GLUT4 content remained unchanged whatever the diet and treatment (Fig. 5A). 
A

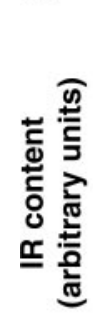

Blot: anti-IRB

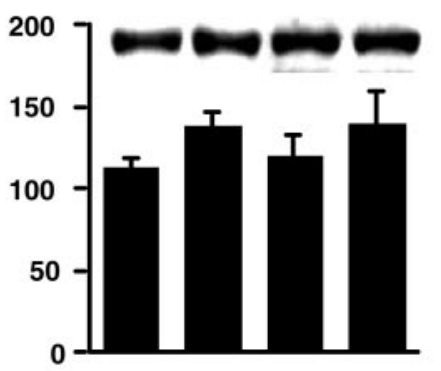

C

Fig. 4. IR, IRS-1, and p $85 \alpha$ protein contents $(A, C, E)$, IR and IRS-1 tyrosine phosphorylation ( $B$ and $D)$, p $85 \alpha$ association with IRS-1 $(F)$, and PI3K activity $(G)$ in muscle. To quantify protein contents, lysates $(100 \mu \mathrm{g})$ were electrophoresed onto $10 \%$ SDS polyacrylamide gel and blotted with anti-IR $\beta$ to identify the $\beta$-subunit of IR $(A)$, with anti-IRS-1 $(C)$ or with anti-p $85 \alpha(E)$. For tyrosine phosphorylation, lysates $(1 \mathrm{mg})$ were immunoprecipitated with anti-PY20 and then blotted with antiIR $\beta(B)$ or anti-IRS-1 $(D)$. To identify $\mathrm{p} 85 \alpha$ associated with IRS-1 $(F)$, lysates (1 mg) were immunoprecipitated with anti-IRS- 1 and then blotted with anti-p85 $\alpha$. Results were quantified by densitometry. Blots are representative of 4 experiments. G: PI3K activity was assayed in PY20 immunoprecipitates by quantification of ${ }^{32} \mathrm{P}$ incorporated into PI(3)P. Results are expressed as means \pm SE; $n=$ 4 rats. $* P<0.05$ vs. control; $\dagger P<0.05$ vs. control + dexa.

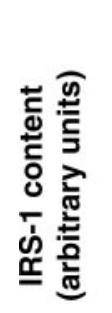

Blot: anti-IRS-1

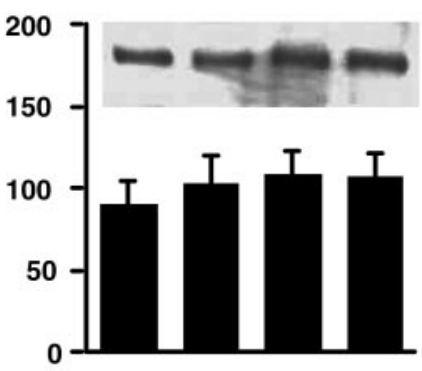

$E$
$F$

$\mathbf{F}$

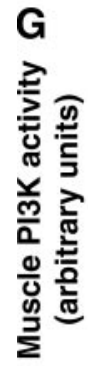

B

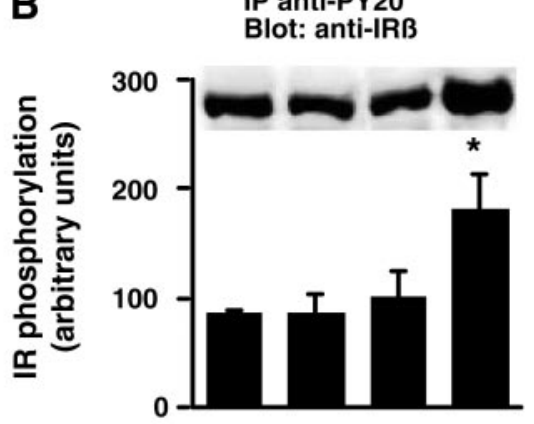

D

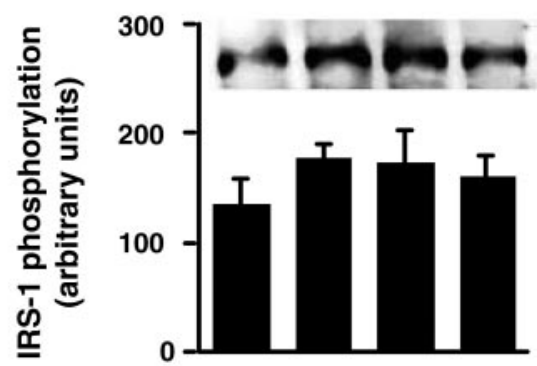

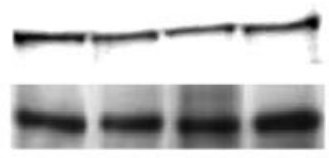

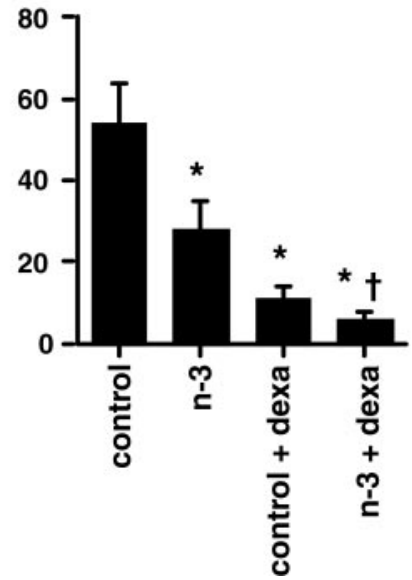

Blot: anti-p85 $\alpha$

IP anti-IRS-1

Blot: anti-p85 $\alpha$
Effect of n-3 diet on IR, IRS-1, PI 3'-kinase, and GLUT4 in adipose tissue. In adipose tissue, IR protein content was unchanged whatever the diet and treatment (Fig. 6A). The n-3 diet increased IR tyrosine phosphorylation by $49 \%$ (not significant; Fig. 6B). Although the n-3 diet increased IRS-1 protein content by $70 \%(P<0.05$; Fig. $6 C)$, IRS-1 tyrosine phosphorylation remained unchanged (Fig. 6D). Dexamethasone increased IR tyrosine phosphorylation with both control $(+137 \%)$ and $n-3$ $(+120 \%)$ diets (both $P<0.05$; Fig. $6 B$ ) and had no effect on IRS-1 tyrosine phosphorylation (Fig. 6D). p85 $\alpha$ protein content was not modified whatever the diet and treatment (Fig. $6 E)$. In contrast to liver and muscle, the n-3 diet increased $\mathrm{p} 85 \alpha$ association with IRS-1 by $71 \%(P<0.05$; Fig. $6 F)$ and increased PI $3^{\prime}$-kinase activity by $74 \%(P<0.05$; Fig. $6 G)$. In dexamethasone-treated rats, the n-3 diet increased p $85 \alpha$ association with IRS-1 by $49 \%(P<0.05)$. Dexamethasone inhibited PI $3^{\prime}$-kinase activity by $65 \%(P<0.05)$. The $n-3$ diet did not amplify the dexamethasone-induced inhibition of PI $3^{\prime}$ kinase activity (Fig. 6G). GLUT4 content was increased by $61 \%$ with the n-3 diet $(P<0.05)$ and was unaffected by dexamethasone (Fig. 5B).

\section{DISCUSSION}

The present study aimed to determine the impact of a very low level of LC-n-3 PUFA ( $0.42 \%$ of calories) on insulin 
A

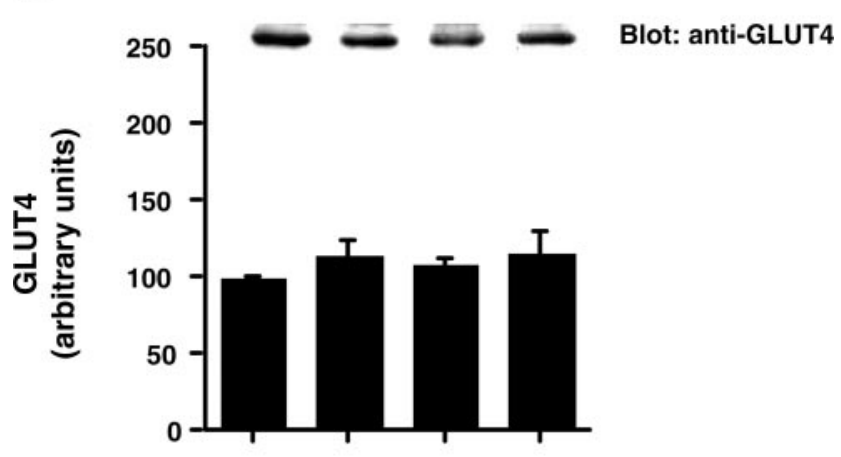

B

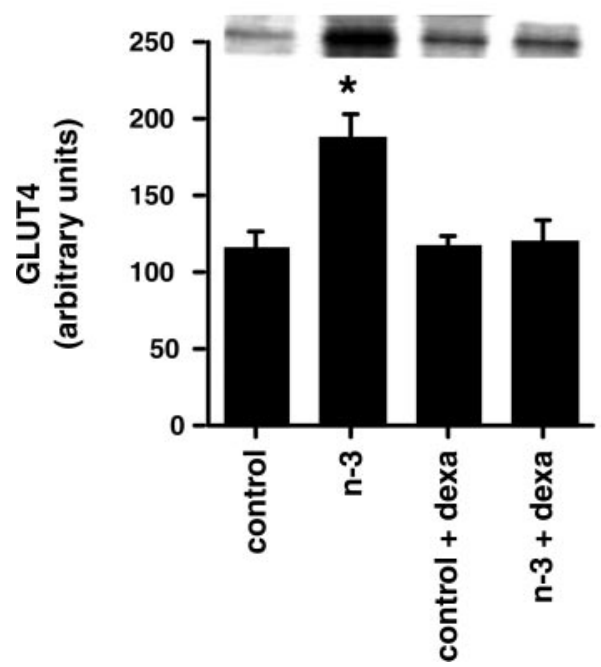

Blot: anti-GLUT4

Fig. 5. GLUT4 protein content in muscle $(A)$ and adipose tissue $(B)$. Lysates $(100 \mu \mathrm{g})$ were electrophoresed onto $10 \%$ SDS polyacrylamide gel and blotted with anti-GLUT4. Immunoblots are representative of 4 experiments; $n=4$ rats. $* P<0.05$ vs. control.

signaling in fed rats. We deliberately chose to study rats in the fed state instead of after insulin injection (the usual way to activate the insulin-signaling pathway in vivo) to be able to evaluate the effect of LC-n-3 PUFA in a true physiological state and to avoid the use of high insulin doses that may not discriminate between insulin and IGF-I receptors. It was clearly demonstrated by Ito et al. (15) that, in the fed state, with exactly the same insulinemia as in the present study, insulin signaling was markedly activated from IR to PI 3 '-kinase. Moreover, GLUT4 translocation and transport are activated in rat muscles after an oral glucose load, demonstrating also the effect of a physiological state on this downstream part of insulin signaling (22). Thus, for these reasons, we can reasonably take for granted that the insulin-signaling pathway was activated solely by the conditions of the fed state in tissues from our rats.

Our study suggests an important contribution of adipose tissue to whole body insulin sensitivity. We demonstrate that LC-n-3 PUFA $(0.42 \%$ of calories) given as FO $(2.2 \%$ of calories) increased PI $3^{\prime}$-kinase activity in adipose tissue, whereas it markedly and specifically decreased it in liver and muscle. Furthermore, FO increased GLUT4 content in adipose tissue alone. Plasma glucose and insulin responses to OGTT, a method used to estimate glucose tolerance and whole body insulin sensitivity, remained unaffected with regard to the LC-n-3 PUFA-induced inhibition of PI 3'-kinase activity in liver and muscle. This contrasts with the marked deterioration of glucose tolerance and insulin sensitivity induced by dexa-
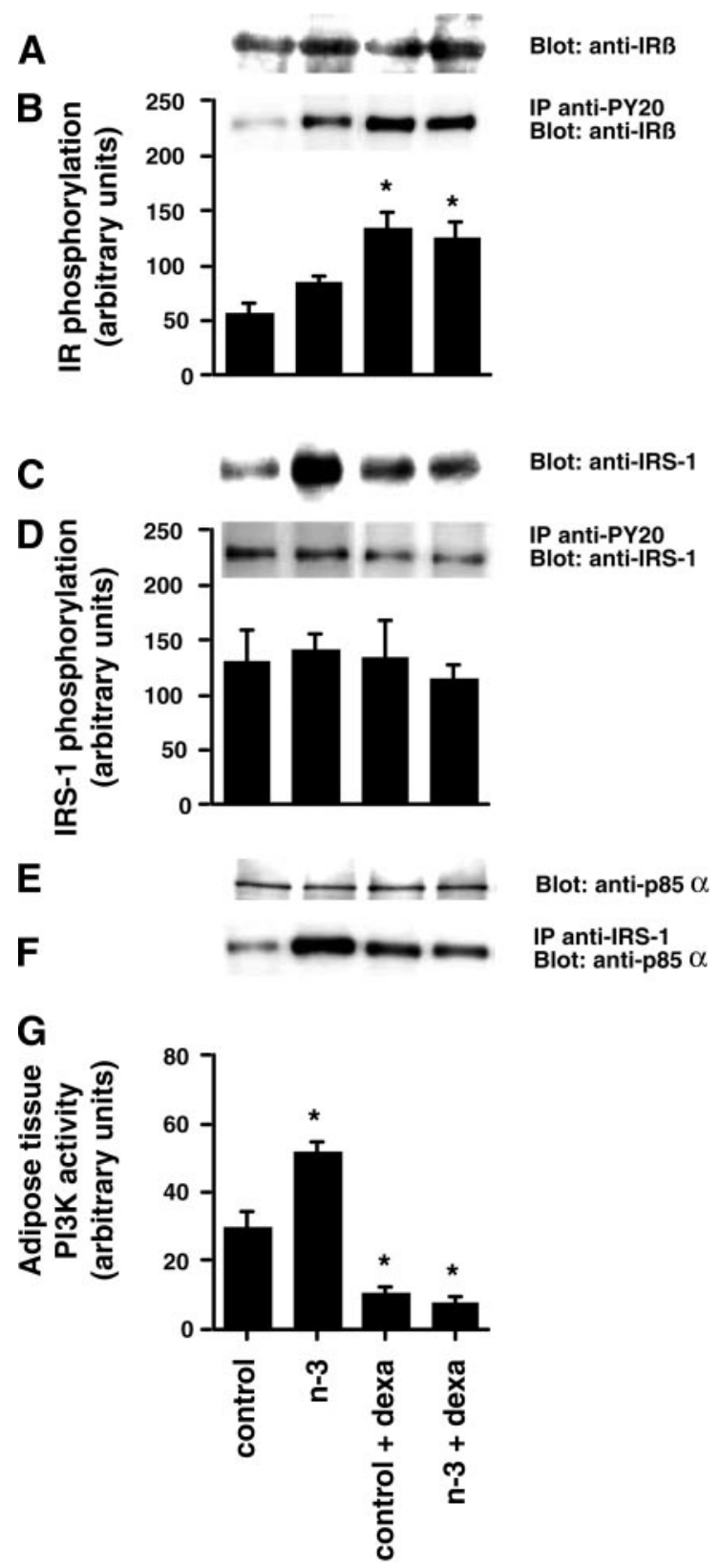

Fig. 6. IR, IRS-1, and p $85 \alpha$ protein contents $(A, C, E)$, IR and IRS- 1 tyrosine phosphorylation $(B$ and $D)$, p $85 \alpha$ association with IRS- $1(F)$, and PI3K activity $(G)$ in adipose tissue. To quantify protein contents, lysates $(100 \mu \mathrm{g})$ were electrophoresed onto $10 \%$ SDS polyacrylamide gel and blotted with anti-IR $\beta$ to identify the $\beta$-subunit of IR $(A)$, with anti-IRS-1 $(C)$ or with anti-p85 $(E)$. For tyrosine phosphorylation, lysates $(1 \mathrm{mg})$ were immunoprecipitated with anti-PY20 and then blotted with anti-IR $\beta(B)$ or anti-IRS-1 $(D)$. To identify p85 $\alpha$ associated with IRS-1 $(F)$, lysates $(1 \mathrm{mg})$ were immunoprecipitated with anti-IRS- 1 and then blotted with anti-p85 $\alpha$. Results were quantified by densitometry. Blots are representative of 4 experiments. $G$ : PI3K activity was assayed in PY20 immunoprecipitates by quantification of ${ }^{32} \mathrm{P}$ incorporated into $\mathrm{PI}(3) \mathrm{P}$. Results are expressed as means $\pm \mathrm{SE} ; n=4$ rats. $* P<0.05$ vs. control. 
methasone, which depressed PI 3'-kinase activity not only in liver and muscle but also in adipose tissue. This difference between LC-n-3 PUFA and dexamethasone effects strongly suggests that, in rats consuming $2.2 \%$ of calories from fat as FO, the enhancement of PI $3^{\prime}$-kinase activity and GLUT4 content in adipose tissue was able to compensate for the impairment of insulin signaling in liver and muscle.

It is quite probable that the increase in PI 3'-kinase activity and GLUT4 content in adipose tissue was associated with an increase in glucose transport in this tissue. Indeed, Shepherd et al. (29) showed that GLUT4 overexpression in adipose tissue increased glucose transport in this tissue. Moreover, Rizkalla et al. (26) demonstrated that dietary FO (30\% of calories) led to a marked increase in insulin-stimulated glucose utilization in adipose tissue. Whether an increase in GLUT4 solely in adipose tissue is able to compensate for whole body insulin resistance has also been demonstrated by Tozzo et al. (38), who showed that overexpression of GLUT4 in adipose tissue ameliorated insulin resistance in rats treated with streptozotocin. Conversely to adipose tissue, a decrease in muscle glucose transport is very likely in rats fed an n-3 diet and/or treated by dexamethasone. Indeed, a specific inhibition of muscle PI 3'-kinase by wortmannin (42) or LY-294002 (30) has been demonstrated to lead to a severe impairment of glucose transport. Thus, in rats fed the n-3 diet, the lack of alteration of glucose tolerance and insulin response with regard to the marked inhibition of PI 3'-kinase in liver and muscle can be explained by a compensatory increase in glucose transport in adipose tissue due to both increases in PI $3^{\prime}$-kinase activity and GLUT4 content. This highlights the important contribution of adipose tissue to whole body glucose metabolism.

In adipose tissue, the increase in PI $3^{\prime}$-kinase activity can be explained by its increased association with IRS-1. The basic mechanisms of this increased association remain unclear. It was not explained by an increase in IRS-1 tyrosine phosphorylation or in $\mathrm{p} 85 \alpha$ subunit protein content. The alteration of compartmentalization of IRS-1 and PI 3'-kinase by LC-n-3 PUFA may have played a role. Indeed, intracellular compartments have been demonstrated to play an important role in the generation of downstream insulin-signaling events in liver (2) and in adipocytes $(14,41)$. In a murine adipocyte cell line (3T3-L1), insulin redistributes mainly p85 to intracellular lowdensity microsome membranes to stimulate GLUT4 translocation (41). In the present study, LC-n-3 PUFA could have altered p $85 \alpha$ trafficking and/or its association with IRS-1. The lack of aggravation of dexamethasone-induced inhibition of PI 3 '-kinase activity in adipose tissue, which contrasts with what was observed in liver and muscle, could be explained by a resultant opposite effect of dexamethasone and LC-n-3 PUFA on PI 3'-kinase activity, the effect of dexamethasone remaining predominant.

In liver, LC-n-3 PUFA reduced PI 3'-kinase activity without significant changes in upstream signaling. This strongly suggests that the inhibitory effect of LC-n-3 PUFA on PI 3'-kinase activity exerted at the level of its catalytic subunit. We could not exclude the possibility that the p50 or p55 subunit of PI $3^{\prime}$-kinase is modulated by n-3 PUFA and could thus affect p $85 \alpha / \mathrm{p} 110$ activity in a tissue-specific manner (16). Finally, whether the $\mathrm{p} 85 \alpha$ subunit redistributes between endosomal membranes and plasma membranes as in liver (2) and adipo- cytes $(14,41)$, LC-n-3 PUFA may have interfered with such a process.

In muscle, LC-n-3 PUFA also inhibited PI 3'-kinase activity without alteration of upstream insulin signaling and amplified dexamethasone-induced inhibition of PI 3'-kinase activity, whereas GLUT4 content was affected neither by dexamethasone treatment as previously reported $(12,23)$ nor by LC-n-3 PUFA. This does not exclude that GLUT4 content into plasma membranes was decreased secondarily to decreased translocation of GLUT4, itself being the consequence of decreased PI $3^{\prime}$-kinase activity. Indeed, it has been clearly shown that specific inhibition of muscle PI 3'-kinase by wortmannin (42) or LY-294002 (30) inhibited both GLUT4 translocation and then glucose transport.

The 4-wk consumption of an amount of FO of $2.2 \%$ of energy intake was sufficient to induce a marked increase in incorporation of 20:5 n-3 and 22:6n-3 into phospholipids of liver, muscle, and adipose tissue crude membranes. It is of interest to note that incorporation of LC-n-3 PUFA into membranes was very similar in liver and muscle, whereas inhibition of PI 3'-kinase activity was identical. We can speculate that the alteration of lipid composition of membranes induced by the $n-3$ diet altered the redistribution of the $p 85 \alpha$ subunit of PI 3 '-kinase to the plasma membrane (2) and/or the catalytic activity of the p110 subunit or its association with the p85 $\alpha$ subunit through conformational changes or lipid-protein interaction. Recently, it has been shown that ether-linked phospholipids composing phosphatidylcholine stimulated PI 3'-kinase activity in murine pre-B lymphocytes (19). Even though the effect was observed in pre-B lymphocytes and PI 3'-kinase was stimulated, these data reinforce the hypothesis of the possible contribution of the alteration of phospholipid composition by n-3 diet to the inhibition of PI $3^{\prime}$-kinase in liver and muscle in the present study.

The 5-day dexamethasone treatment induced both a marked weight loss and a decrease in energy intake as previously reported (28). Dexamethasone also induced a higher glycemic and insulinemic response to the OGTT, consistent with the development of insulin resistance (28). FO did not prevent these alterations. This contrasts with the observation of a preventive effect of highly saturated or n-6 PUFA diet-induced insulin resistance by a high level of FO (20\% of calories; for a review, see Ref. 9). This different effect could be due to the fact that the very low levels of FO given to rats $(2.2 \%$ of calories) in the present study inhibited per se PI $3^{\prime}$-kinase activity in liver and muscle, whereas a high level of FO (20\% of calories) prevented the decrease in PI 3'-kinase activity and GLUT4 content in muscle of rats fed a high n-6 PUFA diet (35). Holness et al. (13) observed that a low level (7\% of calories) of dietary FO substituted into a high-fat diet (20\% of calories from saturated fat) induced liver insulin resistance while preventing muscle insulin resistance (13), also demonstrating a tissue-specific effect of LC-n-3 PUFA. It is also possible that dexamethasone had a too-potent effect to be alleviated by a low dose of LC-n-3 PUFA.

The present data also bring some insight about effects of LC-n-3 PUFA in patients with type 2 diabetes. In such patients, dietary FO supplementation, given at a very similar level as in the present study on a body weight basis, ameliorates neither insulin resistance nor glycemic control $(21,24,25)$. Luo et al. (18) showed that 2 mo of moderate FO intake (1.8 g/day 
EPA + DHA) did not restore the low level of GLUT4 mRNA in adipose tissue. Thus the lack of effect of LC-n-3 PUFA toward insulin resistance in patients with type 2 diabetes might be explained by their inability to reverse the defect of insulin signaling in adipose tissue and muscle, as shown in rats treated by dexamethasone in the present study.

In conclusion, the present study demonstrates that, in a standard low-fat diet (6.6\% of calories from fat), LC-n-3 PUFA given at a very low level ( $0.42 \%$ of calories) exerts a tissuespecific regulation on PI $3^{\prime}$-kinase activity, e.g., a potent inhibitory effect in liver and muscle contrasting with a potent stimulatory effect in adipose tissue in normo-insulin-sensitive rats. The maintenance of whole body glucose homeostasis despite profound inhibition of PI 3'-kinase activity in liver and muscle suggests an important role of adipose tissue for control of glucose homeostasis. Such a low dose of LC-n-3 PUFA was unable to prevent whole body insulin resistance induced by dexamethasone, which can be explained by its inability to prevent the decrease in PI $3^{\prime}$-kinase activity at once in liver, muscle, and adipose tissue.

\section{ACKNOWLEDGMENTS}

Technical help from Nicole Hourmant was deeply appreciated. We thank Danièle Lucas and Marie-Pierre Moineau for the assays of glucose and insulin. We thank Prof. Pascal Ferré (INSERM U465) for helpful discussion of our results.

\section{GRANTS}

This work was supported by a grant from Région Bretagne and Région Pays de la Loire.

\section{REFERENCES}

1. Adamo M, Simon J, Rosebrough RW, McMurtry JP, Steelke NC, and LeRoith D. Characterization of the chicken muscle insulin receptor. Gen Comp Endocr 68: 456-465, 1987.

2. Balbis A, Baquiran G, Bergeron JJ, and Posner BI. Compartmentalization and insulin-induced translocations of insulin receptor substrates, phosphatidylinositol 3-kinase, and protein kinase B in rat liver. Endocrinology 141: 4041-4049, 2000.

3. Bergé JP, Gouygou JP, Dubacq JP, and Durand P. Reassessment of lipid composition of the diatom Skeletonema costatum. Phytochemistry 39: 1017-1021, 1995.

4. Bergé JP, Debiton E, Dumay J, Durand P, and Barthomeuf C. In vitro anti-inflammatory and anti-proliferative activity of sulfolipids from the red alga Porphyridium cruentum. J Agric Food Chem 50: 6227-6232, 2002.

5. Bjornholm M, Kawano Y, Lehtihet M, and Zierath JR. Insulin receptor substrate-1 phosphorylation and phosphatidylinositol 3-kinase activity in skeletal muscle from NIDDM subjects after in vivo insulin stimulation. Diabetes 46: 524-527, 1997.

6. Bligh EG and Dyer WJ. A rapid method of total lipid extraction and purification. Can J Biochem Physiol 37: 911-917, 1959.

7. Bonadonna RC, Del Prato S, Bonora E, Saccomani MP, Gulli G, Natali A, Frascerra S, Pecori N, Ferrannini E, Bier D, Cobelli C, and DeFronzo RA. Roles of glucose transport and glucose phosphorylation in muscle insulin resistance of NIDDM. Diabetes 45: 915-925, 1996.

8. DeFronzo RA. Pathogenesis of type 2 diabetes mellitus. Med Clin North Am 88: 787-835, 2004.

9. Delarue J, LeFoll C, Corporeau C, and Lucas D. N-3 long chain polyunsaturated fatty acids: a nutritional tool to prevent insulin resistance associated to type 2 diabetes and obesity? Reprod Nutr Dev 44: 289-299, 2004.

10. Dimitriadis G, Leighton B, Parry-Billings M, Sasson S, Young M, Krause U, Bevan S, Piva T, Wegener G, and Newsholme EA. Effects of glucocorticoid excess on the sensitivity of glucose transport and metabolism to insulin in rat skeletal muscle. Biochem $J$ 321: 707-712, 1997.

11. Ducluzeau PH, Perretti N, Laville M, Andreelli F, Vega N, Riou JP, and Vidal H. Regulation by insulin of gene expression in human skeletal muscle and adipose tissue. Evidence for specific defects in type 2 diabetes. Diabetes 50: 1134-1342, 2001.

12. Haber RS and Weinstein SP. Role of glucose transporters in glucocorticoid-induced insulin resistance. GLUT4 isoform in rat skeletal muscle is not decreased by dexamethasone. Diabetes 41: 728-735, 1992.

13. Holness MJ, Greenwood GK, Smith ND, and Sugden MC. Diabetogenic impact of long-chain omega-3 fatty acids on pancreatic beta-cell function and the regulation of endogenous glucose production. Endocrinology 144: 3958-3968, 2003.

14. Inoue G, Cheatham B, Emkey R, and Kahn CR. Dynamics of insulin signaling in 3T3-L1 adipocytes. Differential compartmentalization and trafficking of insulin receptor substrate (IRS)-1 and IRS-2. J Biol Chem 273: $11548-11555,1998$

15. Ito Y, Ariga M, Takahashi SI, Takenaka A, Hidaka T, and Noguchi T. Changes in tyrosine phosphorylation of insulin receptor and insulin receptor substrate-1 (IRS-1) and association of $\mathrm{p} 85$ subunit of phosphatidylinositol 3-kinase with IRS-1 after feeding in rat liver in vivo. $J$ Endocr 154: 267-273, 1997.

16. Inukai K, Funaki M, Ogihara T, Katagiri H, Kanda A, Anai M, Fukushima Y, Hosaka T, Suzuki M, Shin BC, Takata K, Yazaki Y, Kikuchi M, Oka Y, and Asano T. p85 $\alpha$ Gene generates three isoforms of regulatory subunit for phosphatidyl-inositol 3-kinase, p50 $\alpha$, p55 $\alpha$, and p85 $\alpha$, with different PI 3-kinase activity elevating responses to insulin. J Biol Chem 272: 7873-7882, 1997.

17. Krook A, Bjornholm M, Galuska D, Jiang XJ, Fahlman R, Myers MG Jr, Wallberg-Henriksson H, and Zierath JR. Characterization of signal transduction and glucose transport in skeletal muscle from type 2 diabetic patients. Diabetes 49: 284-292, 2000.

18. Luo J, Rizkalla SW, Vidal H, Oppert JM, Colas C, Boussairi A, Guerre-Millo M, Chapuis AS, Chevalier A, Durand G, and Slama G. Moderate intake of n-3 fatty acids for 2 months has no detrimental effect on glucose metabolism and could ameliorate the lipid profile in type 2 diabetic men. Results of a controlled study. Diabetes Care 21: 717-724, 1998.

19. Misra S, Ghosh A, and Varticovski L. Naturally occurring ether-linked phosphatidylcholine activates phosphatidylinositol 3-kinase and stimulates cell growth. J Cell Biochem 55: 146-153, 1994.

20. Mol HGJ, Janssen HG, and Cramers CA. Large volume sample introduction using temperature programmable injectors: implications of liner diameter. J High Res Chromatogr 18: 19-27, 1995.

21. Montori VM, Farmer A, Wollan PC, and Dinneen SF. Fish oil supplementation in type 2 diabetes: a quantitative systematic review. Diabetes Care 23: 1407-1415, 2000.

22. Napoli R, Hirshman MF, and Horton ES. Mechanisms of increased skeletal muscle glucose transport activity after an oral glucose load in rats. Diabetes 44: 1362-1368, 1995.

23. Oda N, Nakai A, Mokuno T, Sawai Y, Nishida Y, Mano T, Asano K, Itoh Y, Kotake M, and Kato S. Dexamethasone-induced changes in glucose transporter 4 in rat heart muscle, skeletal muscle and adipocytes. Eur J Endocrinol 133: 121-126, 1995.

24. Puhakainen I, Ahola I, and Yki-Jarvinen H. Dietary supplementation with n-3 fatty acids increases gluconeogenesis from glycerol but not hepatic glucose production in patients with non-insulin-dependent diabetes mellitus. Am J Clin Nutr 61: 121-126, 1995.

25. Rivellese AA, Maffettone A, Iovine C, Di Marino L, Annuzzi G, Mancini M, and Riccardi G. Long-term effects of fish oil on insulin resistance and plasma lipoproteins in NIDDM patients with hypertriglyceridemia. Diabetes Care 19: 1207-1213, 1996.

26. Rizkalla SW, Alamowitch C, Luo J, Bruzzo F, Boillot A, Chevalier A, and Slama G. Effect of dietary fish oil on insulin action in fat cells of control and non-insulin-dependent rats. Ann NY Acad Sci 683: 213-217, 1993.

27. Ryder JW, Yang J, Galuska D, Rincon J, Bjornholm M, Krook A, Lund S, Pedersen O, Wallberg-Henriksson H, Zierath JR, and Holman GD. Use of a novel impermeable biotinylated photolabeling reagent to assess insulin- and hypoxia-stimulated cell surface GLUT4 content in skeletal muscle from type 2 diabetic patients. Diabetes 49: 647-654, 2000.

28. Saad MJ, Folli F, Kahn JA, and Kahn CR. Modulation of insulin receptor, insulin receptor substrate-1 (IRS-1) and phosphatidylinositol 3-kinase in liver and muscle of dexamethasone treated rats. J Clin Invest 92: 2065-2072, 1993.

29. Shepherd PR, Gnudi L, Tozzo E, Yang H, Leach F, and Kahn BB. Adipose cell hyperplasia and enhanced glucose disposal in transgenic mice 
overexpressing GLUT4 selectively in adipose tissue. J Biol Chem 268: 22243-22246, 1993.

30. Shepherd PR, Withers DJ, and Siddle K. Phosphoinositide 3-kinase: the key switch mechanism in insulin signaling (Review). Biochem $J$ 333: 471-490, 1998 [Erratum in Biochem J 335: 711, 1998].

31. Shulman GI. Cellular mechanisms of insulin resistance. J Clin Invest 106: 171-176, 2000.

32. Simoncikova P, Wein S, Gasperikova D, Ukropec J, Certik M, Klimes I, and Sebokova E. Comparison of the extrapancreatic action of gammalinolenic acid and n-3 PUFAs in the high fat diet-induced insulin resistance [corrected]. Endocr Regul 36: 143-149, 2003 [Erratum in: Endocr Regul 37: 20, 2003].

33. Storlien LH, Jenkins AB, Chisholm DJ, Pascoe WS, Khouri S, and Kraegen EW. Influence of dietary fat composition on development of insulin resistance in rats. Diabetes 40: 280-289, 1991.

34. Storlien LH, Kraegen EW, Chisholm DJ, Ford GL, Bruce DG, and Pascoe WS. Fish oil prevents insulin resistance induced by high fat feeding in rats. Science 237: 885-888, 1987.

35. Taouis M, Dagou C, Ster C, Durand G, Pinault M, and Delarue J. n-3 Polyunsaturated fatty acids prevent the defect of insulin receptor signaling in muscle. Am J Physiol Endocrinol Metab 282: E664-E671, 2002.

36. Taouis M, Derouet M, Caffin JP, Chavanieu A, and Simon J. Insulin receptor, and insulin sensitivity in a chicken hepatoma cell line. Mol Cell Endocrinol 96: 113-123, 1993.
37. Tappy L, Randin D, Vollenweider P, Vollenweider L, Paquot N, Scherrer U, Schneiter P, Nicod P, and Jequier E. Mechanisms of dexamethasone-induced insulin resistance in healthy humans. J Clin Endocrinol Metab 79: 1063-1069, 1994.

38. Tozzo E, Gnudi L, and Kahn BB. Amelioration of insulin resistance in streptozotocin diabetic mice by transgenic overexpression of GLUT4 driven by an adipose-specific promoter. Endocrinology 138: 1604-1611, 1997.

39. Vessby B, Unsitupa M, Hermansen K, Riccardi G, Rivellese AA, Tapsell LC, Nalsen C, Berglund L, Louheranta A, Rasmussen BM, Calvert GD, Maffetone A, Pedersen E, Gustafsson IB, and Storlien LH. Substituting dietary saturated for monounsaturated fat impairs insulin sensitivity in healthy men and women: the KANWU Study. Diabetologia 44: 312-319, 2001.

40. Weinstein SP, Wilson CM, Pritsker A, and Cushman SW. Dexamethasone inhibits insulin-stimulated recruitment of GLUT4 to the cell surface in rat skeletal muscle. Metabolism 47: 3-6, 1998.

41. Yang J, Clarke JF, Ester CJ, Young PW, Kasuga M, and Holman GD. Phosphatidylinositol 3-kinase acts at an intracellular membrane site to enhance GLUT4 exocytosis in 3T3-L1 cells. Biochem J 313: 125-131, 1996.

42. Yeh JI, Gulve EA, Rameh L, and Birnbaum MJ. The effects of wortmannin on rat skeletal muscle. Dissociation of signaling pathways for insulin- and contraction-activated hexose transport. J Biol Chem 270: 2107-2111, 1995.

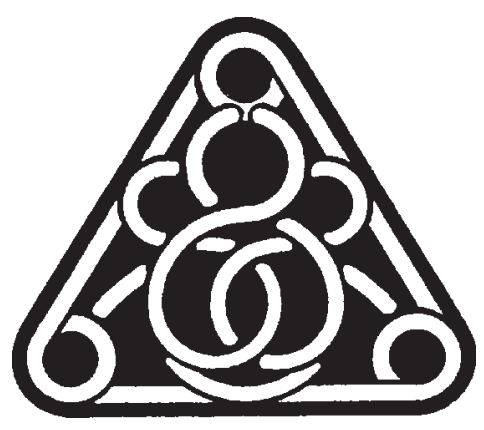

